Revista Brasileira de Ecoturismo, São Paulo, v.1, n.1, setembro, 2008.

ISSN: 1983-9391 - SEÇÃO: ARTIGOS

Raimundo, S. Conservação da natureza e turismo no Núcleo Picinguaba do Parque Estadual da

Serra do Mar (SP). Revista Brasileira de Ecoturismo, São Paulo, v.1, n.1, 2008, pp.10-41.

\title{
Conservação da natureza e turismo no Núcleo Picinguaba do Parque Estadual da Serra do Mar (SP)
}

Sidnei Raimundo

\section{RESUMO}

Este artigo apresenta algumas características do entendimento da natureza pela sociedade ocidental e discute como o conceito de Unidades de Conservação se insere nesse contexto. Com base no modelo adotado pelo Brasil para o manejo destas Unidades de Conservação, são apresentados os principais problemas e conflitos que ocorrem presentemente nestas unidades. Utilizando como área de estudo o Núcleo Picinguaba do Parque Estadual da Serra do Mar, situado no litoral norte do Estado de São Paulo, são apresentadas informações para o planejamento e gestão do veraneio e do Ecoturismo no Núcleo Picinguaba, que visam contribuir para redução dos problemas encontrados no manejo destas áreas protegidas.

\section{PALAVRAS-CHAVE}

Unidades de Conservação, Planejamento do Ecoturismo, Parque Estadual da Serra do Mar

\section{Nature Conservation and Tourism in Núcleo Picinguaba - Serra do Mar State Park, São Paulo, SP - Brazil}

\section{ABSTRACT}

This paper presents some information of the understanding the nature by Western society and discusses how the concept of the protect-areas falls in that context. Based on the model adopted by Brazil for the conservation management of these areas, we have showed the main problems and conflicts that currently occur in these protect-areas. Using as study case the "Núcleo Picinguaba" of the Parque Estadual da Serra do Mar (Serra do Mar State Park), located on the coast north of the Sao Paulo's state (Brazil), we have presented information to the ecotourism and the summering's planning and management of the "Núcleo Picinguaba", which aim to help reduce problems found in the management of these protected-areas.

\section{KEY-WORDS}

Protect Areas, Ecotourism Planning, Serra do Mar State Park

As concepções modernas de conservação da natureza e suas implicações sócio-espaciais no litoral norte de Ubatuba (SP)

A partir da idade moderna, a sociedade ocidental, sobretudo a européia, muda drasticamente sua visão acerca da natureza.

As montanhas em meados do século XVII eram odiadas como estéreis 'deformidades', 'verrugas', 'furúnculos', 'monstruosas excrescências', 'refugo da terra', mas tinham se transformado cerca de um século depois, em objetos da mais elevada admiração estética" (THOMAS, 1988, p.307). 
As explicações para essas mudanças de gosto pela natureza selvagem, estão associadas, segundo Thomas (1988) aos melhoramentos de comunicação, que tornaram as montanhas e outros locais de difícil acesso mais próximas dos moradores da cidade, tornando-as menos proibitivas para estes; aos avanços da ciência e melhorias de técnicas de navegação que desmistificavam os temores do homem em relação aos oceanos e à praia. Além disso, ocorreu um gosto pela jardinagem, paisagismo e outras formas de representar a natureza. Nesse bojo, as artes e literatura reforçavam o imaginário do Homem europeu da idade moderna pelas paisagens pouco humanizadas. Assim:

em fins do século XVIII a antiga referência por paisagens cultivadas e dominada pelo homem conhecia uma contestação radical. Encorajadas pela sua facilidade para viajar e por não estarem diretamente envolvidas no processo agrícola, as classes educadas vieram a atribuir importância sem precedentes à contemplação da paisagem e à apreciação do cenário rural (THOMAS, 1988, pp. 316317).

Desta forma, a natureza passa a ser apreendida de maneira diferente pelo mundo ocidental moderno, que atribuía a ela alguns valores e sentimentos até então não experimentados: a mudança de gosto pela observação e sensação de espaços abertos, onde predominavam o inculto (terras não cultivadas), que dava a ao apreciador a sensação de liberdade.

A chegada de espécies exóticas na Europa, oriundas do novo mundo contribuiu para essa mudança de visão da natureza. Os esforços para "catalogar plantas e animais e as coleções em museus, jardins zoológicos e botânicos aumentaram o gosto do europeu acerca da natureza desconhecida e fizeram surgir as primeiras idéias a respeito de conservação de espécies" (THOMAS, 1988, pp.328329)

É com essa mudança na visão de natureza do homem moderno que surgem as primeiras Unidades de Conservação. Baseada nessa visão, Diegues $(1998,1993)$ traça um histórico de criação de Unidades de Conservação. Para ele, a concepção de áreas protegidas modernamente entendidas tem suas raízes no século XIX. Com o movimento de conservação da natureza que se dava na Europa, espaços de proteção foram criados também nos Estados Unidos, a fim de proteger a vida selvagem (wilderness) ameaçada. Esse conceito ganhou força nos Estados Unidos, até mais do que na Europa, pois os EUA, recém tornado independente, necessitava de algum elemento que lhes dessem identidade, como justificativa de construção da nação. $E$ as extensas paisagens naturais (ou com baixa interferência humana) norteamericanas eram um desses elementos de identidade, diferentemente das paisagens européias já há muito humanizadas.

Os idealizadores dessa visão de mundo, nos Estados Unidos, indicavam que a natureza era destruída pela civilização urbano-industrial. Essa visão criada na 
Raimundo, S.

natureza cercadas por outras formas de usos, para que o homem moderno pudesse admirá-la e reverenciá-la. Para Rodman (1973) a criação de parques obedeceu então, uma visão antropocêntrica, na medida em que beneficiava as populações urbanas e valorizava, principalmente, as motivações estéticas, religiosas e culturais dos seres humanos.

Segundo Diegues (1993), o Brasil herdou o modelo norte-americano de implantação de Unidades de Conservação, embora já existisse uma legislação convencional anterior com muitos artigos de restrições de usos de recursos, como o Código de Águas e o Primeiro Código Florestal Brasileiro, ambos da década de 1930, entre outros diplomas legais. Urban (1998) fez uma revisão sobre as leis de proteção à natureza desde o Brasil colônia. Essa autora indica que $01^{\circ}$ Código Florestal Brasileiro, de 1934, causou uma grande revolução conceitual ao limitar o direito de propriedade, subordinando-o ao interesse coletivo. Além disso, abriu espaço para a criação do Conselho Florestal Federal, que tinha como atribuição o cumprimento do Código.

No interior das Unidades de Conservação de proteção integral, a legislação é bastante restritiva, proibindo a presença de moradores e outras atividades como, por exemplo, a instalação de segundas residências. Práticas de Ecoturismo ou turismo na natureza, embora permitidas, também sofrem limitações da legislação ambiental ou da administração dessas áreas, com a indicação da necessidade de um planejamento criterioso (CEBALLOS-LASCURAIN, 1995).

Contudo, numa breve avaliação das atividades praticadas no interior e entorno das Unidades de Conservação brasileiras, dentre elas o Parque Estadual da Serra do Mar, objeto deste trabalho, verificam-se várias modalidades de usos nessas áreas, sendo boa parte deles ilegais. Diante desse quadro, há sérios conflitos entre os usuários e moradores das Unidades de Conservação, com a legislação que proíbe o "uso direto" de recursos naturais, ou seja, aquele que envolve coleta e uso, comercial ou não, dos recursos naturais (Alínea X do Artigo $2^{\circ}$, do SNUC - Sistema Nacional de Unidades de Conservação, Lei Federal n 9.985, de 18 de Julho de 2000).

Diegues (2000a) aponta que o modelo norte-americano adotado pelo Brasil na criação dessas Unidades de Conservação está em crise, à medida que necessita de grandes contingentes de pessoas para fiscalizar a área, assim como grandes aportes de recursos financeiros. Tal situação, dentro da realidade brasileira, só pode ser conquistada através de empréstimos ou doações de países ricos.

Discutindo os objetivos dessas áreas destinadas à conservação, Miller (1997), faz um resgate sobre a evolução do conceito de áreas protegidas e aponta três enfoques para a criação desses espaços: "i) preservar habitats naturais e sítios culturais considerados valiosos; ii) resguardar e regular o suprimento de recursos de alto valor, como os mananciais de água; e iii) manter as características e a diversidade paisagística" (MILLER, 1997, p. 3).

Diante desses três enfoques apresentados por Miller (op.cit), torna-se difícil proteger ambientes ainda pouco alterados de processos de uso e ocupação mais intensos, como a expansão do veraneio no litoral norte paulista, mas é adequado 
para o planejamento do Ecoturismo, notadamente no interior de uma Unidade de Conservação. Ambas as situações ocorrem no Núcleo Picinguaba.

Nesse sentido, Milano (1997) indica que, em virtude dos vários objetivos de conservação, que na prática muitas vezes não podem ser compatibilizados em uma mesma área, instituíram-se diferentes categorias de manejo de Unidades de Conservação. Obedecendo a essa lógica, o SNUC agrupa as categorias de Unidades de Conservação em dois blocos: o de proteção integral e o de uso sustentável. O primeiro impede o uso direto de recursos naturais, ficando restrito apenas à contemplação da natureza através de práticas de educação e vivência ambiental, além da pesquisa ambiental. $O$ principal objetivo desse bloco de Unidades de Conservação é preservar a natureza e admite-se apenas o uso indireto dos seus recursos (aquele que proíbe coleta e/ou comercialização de recursos naturais). 0 Ecoturismo é a grande atividade sócio-econômica deste bloco.

O segundo bloco tem como objetivo compatibilizar a conservação da natureza com o uso direto sustentável de parcela dos seus recursos naturais. Assim, conforme Hauff (2004) no primeiro grupo visa-se preservar os processos naturais e a diversidade genética com a menor interferência humana possível, permitindo apenas o uso indireto dos recursos. Com o segundo grupo, busca-se conciliar, dentro do possível, a preservação da diversidade genética e dos recursos naturais com o uso direto, moderado e sustentável de alguns destes recursos, limitando a alteração antrópica a um nível compatível com a sobrevivência permanente de comunidades vegetais e animais. Percebe-se com isso, que seja no bloco de proteção integral, seja no de uso sustentável, as atividades de Ecoturismo desempenham importante papel, praticamente exclusivo no primeiro e como fonte complementar de renda e de possibilidades de visitação no segundo.

Mas seja do bloco de proteção integral, seja do de uso sustentável, uma área protegida precisa apresentar atributos naturais e culturais importantes e o SNUC define essas áreas como um

espaço territorial e seus recursos ambientais, incluindo as águas jurisdicionais, com características naturais relevantes, legalmente instituído pelo Poder Público, com objetivos de conservação e limites definidos, sob regime especial de administração, ao qual se aplicam garantias adequadas de proteção"(Artigo $2^{\circ}$, alínea I, do SNUC).

Desta forma, segundo Robim (1999, p. 1) "as Unidades de Conservação têm a finalidade de preservar áreas naturais de interesse científico, ecológico, educativo e de lazer e que por se tratarem de importantes recursos naturais e culturais, de difícil quantificação econômica, devem ser mantidas na forma silvestre e adequadamente manejadas".

Mas o manejo de que trata Robim (1999) apresenta alguns problemas, principalmente quando os limites de Unidades de Conservação desconsideram os 
territórios pré-existentes, notadamente de populações tradicionais, como o dos caiçaras do litoral brasileiro. E a criação de áreas mais restritivas ao uso de recursos naturais, como parques e estações ecológicas, acabou incorporando em seus limites os usos dessas comunidades. Este fato vai gerar sérios conflitos entre a administração dessas unidades e a comunidade, como estudado por Diegues \& Nogara (1994) no litoral sul fluminense, no qual a criação da Unidade de Conservação alterou o modo de vida de camponeses pescadores no Saco do Mamanguá (RJ).

Nesse sentido, Diegues (2000b p.13) "argumenta que um parque sem a presença de moradores é visto com bons olhos pelos gestores dessas áreas por duas razões: a primeira é que tais áreas de grande beleza cênica (sem uso humano) podem gerar renda por meio do Ecoturismo; e a segunda é que fica mais fácil negociar contratos de venda de biodiversidade com empresas multinacionais em espaços desabitados, controlados pelo governo".

Por outro lado, Olmos et.al. (2001) discordam da presença de moradores no interior de uma Unidade de Conservação de proteção integral destacando o quanto as práticas consideradas tradicionais geram extinções à fauna de uma dada região. Para eles, "tal discordância não se baseia em considerações étnicas, mas sim devido ao dano ambiental que essas comunidades tradicionais causam e à ameaça que suas atividades e seu crescimento populacional potencial representam aos ínfimos 3\% do território nacional destinado à proteção integral da biodiversidade, patrimônio de toda a nação brasileira" (OLMOS et.al, 2001, pp. 288-290).

$\mathrm{Na}$ mesma linha, Terborgh \& van Schaik (2002) dão justificativas sobre a importância de não permitir a presença de moradores no interior de um parque. Estes autores apontam que a proteção da biodiversidade é o principal objetivo de uma Unidade de Conservação, a qual deve ser adequadamente protegida de um conjunto de forças destrutivas, muitas ilegais, mas algumas legais. Para Terborgh \& van Schaik, práticas de "desenvolvimento sustentável que não sejam relacionadas ao Ecoturismo são incompatíveis com a conservação da natureza porque, por princípio, seres humanos e animais silvestres não combinam bem" (Terborgh \& van Schaik, 2002, p. 28).

As premissas nas quais Olmos et.al (2001) e Terborgh \& van Schaik (2002) se embasam (incompatibilidade entre seres humanos e animais silvestres) são de difícil aceitação para alguns pesquisadores. Arruda (1997), por exemplo, considera que uma das principais dificuldades na gestão e manutenção das Unidades de Conservação tem sido a relação com as populações humanas que ali vivem e viviam antes da apropriação da área pelo Estado. A legislação acaba sendo um fator altamente impeditivo, pois aborda superficialmente tal questão, desconsiderando as aspirações dessas populações.

Concordando com Arruda (1997), Morsello (2001) relata alguns problemas do modelo norte-americano de criação de Unidades de Conservação. Nos próprios Estados Unidos, segundo essa autora, "ocorreram 300 mortes entre tribos locais e a superintendência do Parque de Yellowstone após a sua criação" (MORSELLO, 2001, p. 143). Yellowstone é um marco na visão de conservação modernamente entendida 
- o modelo norte-americano. Este Parque foi a primeira Unidade de Conservação criada em 1872 que incorporou o conceito de natureza intocada, portanto sem a presença de moradores. O modelo norte-americano foi importado por outros países latino-americanos quando da criação de suas áreas protegidas. "Nesses países, e em outras partes do mundo, populações residentes há séculos em um local foram e são expulsas de suas terras" (MORSELLO, 2001, p. 144).

Como se pode perceber, a situação dessas áreas protegidas no Brasil é bastante complexa. Sobretudo no Nordeste, Sudeste e Centro-Oeste do Brasil, onde atualmente, as Unidades de Conservação são "ilhas" cercadas de pobreza ou de desenvolvimento, sendo que a gestão integrada e a utilização mais adequada, ou consensuada, dos seus recursos naturais não faz parte da estratégia de seus administradores.

Agrava-se a tal situação o modelo norte-americano de criação dessas Unidades de Conservação, que não avalia ou considera os usos ou conhecimentos produzidos por moradores. Na estratégia de ação na qual o gerenciamento das Unidades de Conservação está pautado, parte-se do pressuposto que a sociedade, independente de suas características, produz impactos negativos no ambiente. Não são consideradas, portanto, as distinções entre as várias formas de organização da sociedade - os seus modos de produção -, tais como indígenas, tradicionais, urbanoindustrial, entre outras (VIANNA, 1996).

Como visto, o debate sobre a presença ou não de moradores tradicionais no interior de Unidades de Conservação é intenso. Diante desse quadro de problemas, o Ecoturismo pode se consolidar com um poderoso instrumento de gestão, podendo ser utilizado para dirimir conflitos entre a gestão de uma Unidade de Conservação e os moradores da área. Nesse sentido, pode ser pensado como alternativa de renda dessas comunidades tradicionais, com a capacitação de monitores e condutores em trilhas e demais atrativos em uma Unidade de Conservação; pela vivência das práticas culturais destas comunidades, com o conhecimento de suas técnicas e ferramentas de produção na pesca, agricultura, entre outras, que podem ser oferecidos ao ecoturista como souvenires na forma de artesanato. Além disso, como vivência de sua expressão cultural, dada pelas práticas imateriais (festas, ritos, danças, músicas, entre outras) dentro de seu universo simbólico de entendimento da natureza. Todas essas atividades são muito apreciadas pelo ecoturista, que não está interessado exclusivamente nas características naturais de um sítio, mas também em como uma comunidade apreendeu a interagir com o ambiente natural que habita, construindo suas ferramentas e técnicas de uso e ocupação.

Estes aspectos estão presentes no contexto do Parque Estadual da Serra do Mar - Núcleo Picinguaba - e seus embates com o avanço do veraneio e turismo, assim como das ações dos caiçaras, que passamos a discutir a seguir. 
Raimundo, S.

\section{A criação do Parque Estadual da Serra do Mar (Núcleo Picinguaba)}

É no contexto mencionado no tópico anterior, considerando todos esses conflitos e problemas, que foi criado o Parque Estadual da Serra do Mar em 1977. Havia à época, três antigas grandes Reservas Florestais ao longo da Serra do Mar em São Paulo: Caraguatatuba, ao norte; Queiroz-Pilões, no Município de Cubatão; e Curucutu-Itariru-Pedro de Toledo, ao sul. Eram três grandes áreas florestadas mas que, do ponto de vista de um instrumento legal de conservação, estavam desconectadas espacialmente. Entre 1973 e 1974, um técnico do Metrô, hoje professor da FAU-USP, Prof. Dr. José Pedro de Oliveira Costa, apresentou projeto ao Governador do Estado de São Paulo, para unir essas três reservas numa única grande Unidade de Conservação.

Nesse ínterim, o prefeito de Ilhabela, no litoral norte paulista, propôs um zoneamento urbano para toda a ilha de São Sebastião (maior ilha do Município de Ilhabela), permitindo loteamentos em quase toda sua área. José Pedro de Oliveira Costa conseguiu permissão do governador para negociar com o prefeito de Ilhabela. Costa fez proposta de delimitar áreas para os loteamentos até a cota de $200 \mathrm{~m}$ no lado da ilha voltado para o canal. Articulou com técnicos do Instituto Florestal e com outras entidades para ter apoio técnico e político. Com os trabalhos de delimitação concluídos, o prefeito concordou com a proposta de proteção da Ilha, permitindo loteamentos apenas no lado voltado para o canal. O governador decretou, então, a criação do Parque Estadual de Ilhabela, em 1977.

Baseado na experiência de Ilhabela, José Pedro de Oliveira Costa retomou o projeto da Serra do Mar, sendo o Parque Estadual da Serra do Mar, decretado no segundo semestre daquele ano (1977).

Importante destacar que o processo de criação desta Unidade de Conservação reveste-se de grandes pressões políticas por parte dos ambientalistas. A população local, conforme apontou Brito (2000) ficou à margem das discussões. Para se ter uma idéia dessas pressões, segundo Hélio Ogawa (técnico do Instituto Florestal que participou da criação do PE da Serra do Mar), o Parque foi delimitado em apenas dois dias, e com o material cartográfico disponível à época. Ogawa e Costa debruçaram-se sobre as cartas topográficas do IBGE da fachada litorânea paulista, a maioria delas datadas de 1973, e com o apoio de fotografias aéreas de 1962, 1973 traçaram os limites do Parque.

De norte para sul, procuraram afastar os limites do Parque de aglomerações urbanas, restringindo-se as fronteiras da unidade, ora na cota de $100 \mathrm{~m}$, ora na de $200 \mathrm{~m}$, de acordo com o tamanho do centro urbano próximo à escarpa da Serra do Mar. Realizaram esses procedimentos desde Ubatuba até Pedro de Toledo, no vale do Ribeira. A idéia inicial era estender os limites do Parque até a divisa com o Paraná. Mas resolveram encerrar os limites sul do Parque em Pedro de Toledo, pois esta Unidade de Conservação já incorporava áreas de 23 municípios e mais de 300 mil 
hectares.

Contudo, é importante mencionar que a criação do Parque Estadual da Serra do Mar também não teve plena concordância entre os órgãos que trabalhavam com a questão ambiental na virada dos anos de 1970 e 1980. O relatório da Comissão Especial de Inquérito da Assembléia Legislativa apontava claramente essas divergências:

Ficou claro um certo desaparelhamento e incompetência técnica e científica no planejamento e implantação de Parques Estaduais...Na Serra do Mar, bastaria construir uma rede de pequenos e médios Parques Estaduais, do tipo tampão, nos altos e nos piemontes da Serra, como evidenciado nas discussões do CONDEPHAAT... Essa política de pequenos parques não corresponde à política do Estado... [que] idealizou um impossível e inviável Parque da Serra do Mar, numa alongada faixa de escarpas que se iniciam na fronteira com o Rio de Janeiro e se estendem até a metade da fachada atlântica paulista. Desta forma, a grande e excepcional Serra do Mar ficará expostas a todos os tipos de saques, incluindo a possibilidade criminosa de um manejo pragmático de suas matas, para fins econômicos, de grandes implicações para a predação da natureza e insignificante lucratividade. (PESCARINI, 1981, p. 20)

Como se pode perceber, os conselheiros do CONDEPHAAT tinham opinião contrária aos técnicos do Instituto Florestal na conservação da Serra do Mar. Contudo, apesar dessas divergências, acabou prevalecendo a delimitação proposta pelos técnicos do Instituto Florestal.

Além das divergências entre os órgãos que trabalhavam com a conservação da natureza em São Paulo, o processo de delimitação do Parque, devido aos recursos tecnológicos disponíveis à época, assim como à rapidez com que foi realizado, acabou incorporando áreas com ocupação humana em seu interior e excluiu alguns remanescentes florestais, que poderiam ser inseridos no limite do Parque. As comunidades do Cambury, da Fazenda, de Picinguaba e parte de Ubatumirim são exemplos dessa incorporação de comunidades na área de estudo. Mais que isso, foram encerradas dentro dos limites do Parque, além das áreas de comunidades tradicionais, outras de segundas residências e atividades comerciais, como as do Canto da Paciência, na Praia da Fazenda da área de estudo.

Embora criado em 1977, as ações de implantação do Parque continuaram restritas àquelas três grandes reservas florestais iniciais, sobre as quais o Estado tinha domínio fundiário. As áreas como seu extremo norte, no Núcleo Picinguaba, permaneceram sem ações efetivas do Estado até 1981, quando a antiga fazenda da Caixa foi incorporada aos limites do Parque. Esta Fazenda situava-se no Sertão e Praia da Fazenda, que englobava duas comunidades caiçaras. Mas o Núcleo Picinguaba abarcava ainda outras áreas ocupadas, como o Cambury, o Sertão de 
Ubatumirim e a Vila de Picinguaba. Além delas, recebendo reflexos das ações do parque, há ainda as comunidades da Praia de Ubatumirim e da Almada. Todas essas localidades estão indicadas na Figura 1.

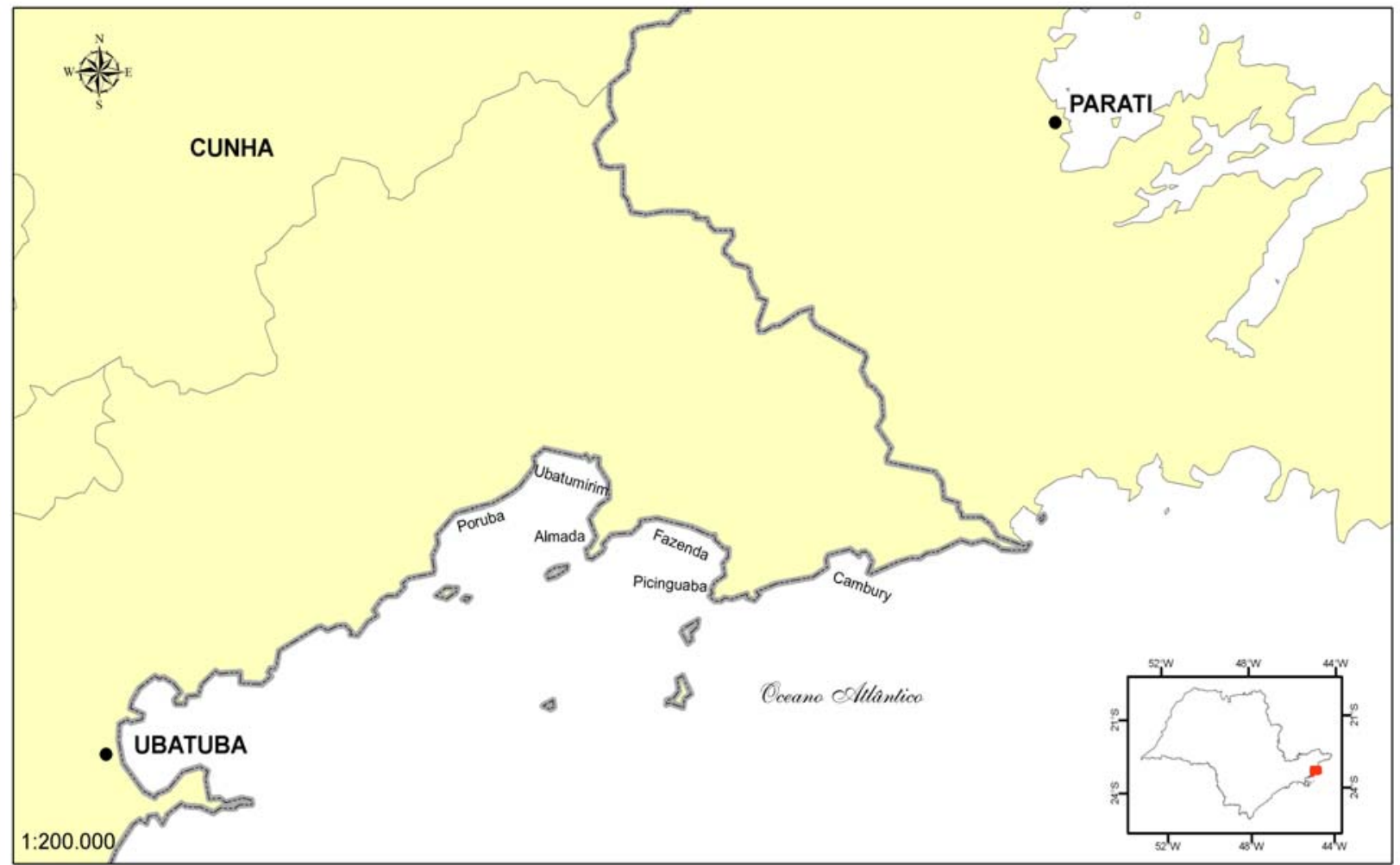

\section{Localidades da Área de Estudo}
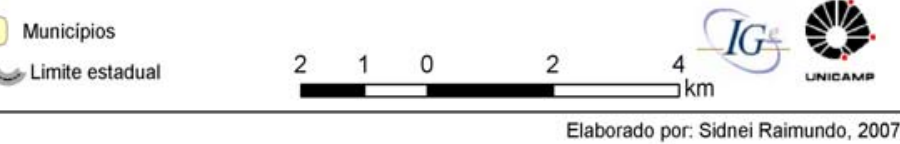

Figura 1: localidades da área de estudo. Elaborado por Sidnei Raimundo.

Nesse período, as áreas desse setor começaram a ser vendidas ou invadidas por terceiros. O Estado interveio, através da extinta Equipe de Resolução de Conflitos de Terras da SUDELPA. Foi levantada a situação fundiária da área em 1983. Nessa época, um acordo verbal foi feito com os moradores do Sertão da Fazenda: as famílias que desejassem continuar na área teriam de respeitar a propriedade do Estado e não realizar novos desmatamentos nem vender suas posses a terceiros. É importante destacar que não fazia parte da cultura do caiçara a regularização de títulos, ou seja, o registro em cartório de suas posses, tratava-se do entendimento da terra como entidade comunal. 
Não foi respeitado o direito de posse dos moradores nem considerado o uso tradicional dessas comunidades à medida que, nesse acordo verbal, os moradores foram orientados a não aumentarem suas áreas de cultivo. Quer dizer, não foi permitido a rotação espacial da agricultura de coivara caiçara.

Em 1981 e ao longo da década de 1980 e parte da de 1990, o instrumento legal seguido pelos agentes ambientais era principalmente o Regulamento de Parques Paulistas (Decreto Estadual № 25.341 de 4 de Junho de 1986).

Baseado numa visão dicotômica de natureza e sociedade - o modelo norteamericano -, o parque era o espaço da natureza sem uso humano direto. Isso pois, segundo esse regulamento paulista,

Os Parques Estaduais dotados de atributos naturais excepcionais, objeto de preservação permanente, submetidas a condição de inalienabilidade e indisponibilidade no seu todo...destinam-se a fins científicos, culturais, educativos e recreativos...O objetivo principal dos Parques Estaduais reside na preservação dos ecossistemas englobados contra quaisquer alterações que os desvirtuem

(Regulamento de Parques Paulistas, parágrafo 1, 2 e 3 do artigo $1^{\circ}$ )

Nessa linha, o regulamento apresentava uma série de proibições, passíveis de multas e apreensão. Algumas dessas proibições contidas no Regulamento e que, na região estudada, eram antes praticadas pelo morador caiçara, em seu modo de vida, passaram a ser proibidas: como a proibição de coleta de frutos, sementes, raízes ou outros produtos dentro da área dos Parques Estaduais (artigo 10); a proibição de qualquer ato de perseguição, apanha, coleta, aprisionamento e abate de exemplares da fauna dos Parques Estaduais, bem como quaisquer atividades que venham a afetar a vida animal em seu meio natural (artigo 13); e suas moradias, pois só eram admitidas residências nos Parques Estaduais, se destinadas aos que exerçam funções inerentes ao seu manejo (administrativas) (artigo 27).

Como se pode constatar pela leitura destes artigos, a legislação ambiental incidente sobre os parques era muito contrastante com a realidade dos moradores caiçaras, fato que gerou problemas na região.

E, para dar conta da aplicação desta legislação e da estruturação do Parque Estadual da Serra do Mar, a SUDELPA e o Instituto Florestal começaram os trabalhos de implantação do Núcleo Picinguaba. Foram contratados funcionários para apoiar trabalhos de campo e foram alocados técnicos que elaboraram laudos para desapropriação de terras e fiscalizarem a área.

O Decreto de desapropriação da Fazenda Picinguaba foi editado em 1986 e cerca de metade de seus ocupantes foi indenizada, migrando para outros bairros do município, como Ubatumirim, fora dos limites do Parque Estadual da Serra do Mar. 
Raimundo, S.

Esse Decreto foi inédito, pois determinava a indenização dos direitos possessórios dos ocupantes pelo Estado, que em geral só reconhecia os direitos de titulares de escrituras de domínio. No entanto, parte dos moradores não foi indenizada, pois suas posses apresentaram sobreposição com outras posses.

Os moradores tradicionais caiçaras que permaneceram na área foram conclamados a um acordo verbal para não venderem suas posses a terceiros (veranistas). A preocupação do Estado era evitar tais vendas para não ocorrer a instalação de loteamentos ou segundas residências na área.

Para exemplificar como a venda de posses e as ações do setor imobiliário eram extremamente ágeis na região, no extremo oeste da Praia da Fazenda - Canto da Paciência -, em uma escritura original de 70 alqueires, foram vendidos lotes que somaram mais de 220 alqueires. Para tentar coibir esse problema, o Instituto Florestal instalou uma base administrativa na área (Km 08 da BR-101) e na Praia da Fazenda para controlar a entrada de materiais de construção para obras clandestinas (OLIVEIRA et.al, 1998).

Com base nisso, é possível pensar nas funções do Parque, apesar de todas suas incongruências de criação e dificuldades de implantação. Essa Unidade de Conservação mostrava-se como um freio às demandas da especulação imobiliária, mas também às necessidades e aspirações das comunidades tradicionais caiçaras. Com a implantação do Parque, os conflitos se intensificaram, seja com os moradores caiçaras, com o cerceamento de seu modo de vida, seja com a especulação imobiliária e o turismo, coibindo ou restringindo as demandas de ocupação de novas áreas, com o embargo de construções, entre outras ações. E a implantação de atividades de Educação Ambiental e Ecoturismo ficaram relegadas a um segundo plano, só vindo a serem pensadas posteriormente, com se tratará mais adiante.

A abertura da BR-101, em 1973, e a chegada da especulação imobiliária fizeram os caiçaras perderem gradativamente seus territórios à orla, o trecho mais valorizado por este setor imobiliário e pelo turismo. Com a criação do Parque em 1977, os caiçaras passam a sofrer pressões também no sertão (anfiteatros da Serra do Mar, fora da linha de costa), ou nas áreas contíguas às vilas na praia, sobre seu modo de vida, como multas e apreensões sobre caça, extrativismo e agricultura.

E é essa estrutura que vai construir novas territorialidades no norte de Ubatuba, resultantes das mudanças de função na região, que passa a ter uma vocação ligada ao turismo e veraneio. A implantação do Núcleo Picinguaba contribui significativamente para a consolidação de um turismo urbano ou veraneio de baixa interferência, mesmo com descaracterizações naturais e culturais, e ao Ecoturismo nos locais fora das áreas urbanas, que se passa a analisar a seguir. 


\section{O Parque Estadual da Serra do Mar e a Estrada Rio-Santos (BR-101) - a estruturação do turismo e veraneio no litoral norte de Ubatuba}

Em trabalho anterior (RAIMUNDO, 2007), pode-se constatar que o ano de 1973 marca uma mudança significativa na área de estudo, com a abertura da BR-101, principal vetor de ocupação da área. E, como visto no tópico anterior, com a criação do Parque Estadual da Serra do Mar, em 1977, este se configura como um limitador destas ocupações e vai oferecer obstáculos à rápida ocupação proporcionada pela pressão imobiliária, justificada no apelo ao turismo e à facilidade de acesso trazida pela BR-101.

A partir da década de 1970, ocorreu a consolidação da função turística da região, com um adensamento de caminhos da BR-101 para a orla marítima. Houve um aumento da densidade de estradas, com outras vicinais sendo construídas ao longo da BR-101, além da intensificação da ocupação ao longo do eixo desta estrada, com a instalação de uma rede serviços, como postos de gasolina, bares, restaurantes, pequenos comércios, entre outros.

A complexidade de relações, representada pelo aumento da rede de circulação, é expressa pelo aumento de atores sociais na região: aos especuladores, turistas, veranistas e migrantes atraídos pelo novo pólo de desenvolvimento que o turismo passou a oferecer, que se verificavam ao longo da década de 1970, somamse, a partir do início dos anos 1980, os técnicos e ambientalistas, para a implantação do Parque (Núcleo Picinguaba).

$\mathrm{E}$, nessa relação entre os diversos atores que compõe a região, pode-se notar o papel do Parque Estadual como sendo um obstáculo ao processo de difusão espacial do uso e ocupação na área. De maneira geral, a densidade da rede de caminhos diminui, seja no sertão, seja na orla, sobretudo no primeiro, com várias trilhas caindo em desuso. Por outro lado, houve o aumento das estradas de terra e das asfaltadas. Com isso diminui-se a densidade (quantidade) de caminhos, mas aumenta a diversidade e intensidade (qualidade) desses. Por essa rede, que oferece maiores possibilidades de circulação, facilitam-se as trocas comerciais e o fluxo de pessoas e de informações (ABLER et.al., 1971).

Há uma dupla causa para esse fenômeno. Um associado à melhoria da qualidade dos fluxos, devido à ampliação das estradas de terra e de asfalto, em substituição às trilhas, principalmente na orla marítima. E, por outro lado, a presença do Parque Estadual, pois a diminuição da rede de trilhas se dá com maior intensidade nas áreas de domínio dessa Unidade de Conservação, principalmente nos sertões.

No dizer de Abler et.al. (1971), localidades se relacionam pela complementaridade e pelas facilidades e densidade de acessos - o grau de intervenção. Desta forma, com a construção da rodovia BR-101 e com a instalação das vicinais a ela subordinadas, os moradores e turistas optam então, pelo eixo da estrada devido à maior facilidade de comunicação e abandonam as trilhas. Trilhas 
Raimundo, S.

que eram utilizadas para comunicação ou caça, como a do vale do Rio Papagaio (transversal às bacias de Ubatumirim e da Fazenda) são praticamente fechadas, sendo constatadas nelas atualmente apenas usos clandestinos, pois estão situadas no interior do Parque Estadual.

Assim, ao longo de todo o trecho em que a BR-101 corta a região há uma grande quantidade de nós (cruzamentos de vias), os quais são predominantemente intersecções de estradas e trilhas dirigindo-se do eixo da BR-101 para as praias e não para o sertão. O que ratifica a função turística e de veraneio da orla.

Tal fato pode ser explicado pela paisagem com forte apelo ao turismo e ao veraneio, devido às características naturais e culturais dessa região. Contudo, localidades como a da Almada, fora dos limites do Parque, vão experimentar um processo de ocupação mais intenso que suas vizinhas ao norte - Picinguaba e Cambury - estas dentro dos limites do Parque. Isso gera na Almada um intenso comércio de compra e venda de lotes, resultando na instalação de equipamentos de lazer e de turismo. Pode-se dizer que a Almada é a localidade que passa pelas maiores transformações na região devido a essas características aqui apontadas. Apresenta um acesso pavimentado, está fora dos limites do Parque e possui um forte apelo às atividades de veraneio e turísticas.

Alguns moradores da Vila de Picinguaba migraram da orla (da faixa de areia) com a pressão da especulação imobiliária. Nessa faixa, sob a função de veraneio e turística, a terra transformou-se em mercadoria muito cara, obrigando alguns antigos moradores a migrarem localmente. Instalaram-se próximo à BR-101, menos valorizada, e desenvolvem atualmente atividades de apoio ao turismo, como os serviços de bares, borracheiros, mecânicos, assim como vendas de artesanato local. Como se trata de uma área dentro dos limites do Parque, a Unidade de Conservação não conseguiu frear mais fortemente os processos de uso e ocupação na área, expressos por este aumento da acessibilidade e circulação na região.

Algumas explicações possíveis para esses fatos estão associadas à acessibilidade e à função. A pavimentação da estrada que liga a BR-101 à Vila de Picinguaba melhorou os acessos, reduzindo o tempo de percurso e acidentes, o que acabou refletindo na valorização dos terrenos da orla nessa vila. Trata-se da única estrada asfaltada que liga a BR-101 a uma comunidade, dentro dos limites do Parque na área de estudo. A pavimentação desta vicinal reforçou a função da vila como espaços de veraneio e de turismo. E a função de conservação, atribuída ao Parque, ficou subordinada àquela função de veraneio e turismo, dentro dos limites da vila, pois as ações de fiscalização não conseguiram reduzir ou coibir as ocupações mais intensas a partir da década de 1980.

Com isso, ocorreu na Vila de Picinguaba um embate entre o morador caiçara tradicional e a especulação imobiliária, fato que promoveu a desterritorialização dos primeiros. Alguns conseguiram permanecer na área da vila, mesmo assim em posições mais interiorizadas - a retro-terra no dizer de Mourão $(2003,1971)$, ou junto 
ao cruzamento da BR-101, como apontado, em terrenos já abertos (desmatados) pela faixa de domínio da rodovia. Como eram áreas já desmatadas, a pressão dos agentes ambientais parece não ter sido intensa, coibindo essas ocupações próximas à BR-101 e a área se consolidou como nova ocupação.

Assim, parte das casas da Vila de Picinguaba que se encontra com frente para o mar são hoje "rugosidades" espaciais, pois elas mantêm a forma das construções caiçaras da época anterior à abertura da BR-101, mas apresentam agora uma função de segunda residência, relacionada à nova vocação de veraneio e turística na vila, que ocorreu a partir da abertura desta rodovia.

Mas mesmo assim é possível pensar no Parque (ou nos agentes ambientais e na legislação ambiental) como um fator de redução dos processos de ocupação na região. Na comunidade da Almada, no trecho compreendido fora dos limites do Parque, a densidade de vias e estradas vicinais se estende ao longo de toda a estrada principal (que liga a comunidade à BR-101), formando um emaranhado de vias e de cruzamentos (nós). Enquanto na Picinguaba, totalmente inserida nos limites do Parque, há apenas duas concentrações (na orla e na estrada) e não generalizada ao longo da estrada que liga esta comunidade à BR-101. Verifica-se, a partir destas informações, que o Parque, mesmo não possuindo uma estrutura e recursos para enfrentar todos os processos de ocupação que ocorrem em seu interior, limita os usos mais exacerbados. Os usos não condizentes com seus objetivos de conservação estão restritos às áreas anteriormente ocupadas (antigas vilas caiçaras), de uma forma concentrada no espaço. Isso pode ser observado na Vila de Picinguaba, ao contrário dos expressos de forma generalizada da Almada.

A Almada é um esporão da Serra do Mar, formando três pequenas praias e o limite do Parque Estadual da Serra do Mar é o interflúvio principal deste esporão. Percebe-se que o setor inserido nos limites do Parque - o leste - apresenta apenas dois cruzamentos de baixa intensidade (trilhas). Enquanto o setor fora dos limites do Parque - oeste - apresenta intensa ocupação, expressa pela densa rede de nós com a estrada asfaltada e outras de terra, além de trilhas.

Embora em menor intensidade, a especulação imobiliária existe dentro do Parque. Mas ela se concentra em áreas anteriormente ocupadas pelos caiçaras, não abrindo novas áreas como na Almada. E é nesse sentido que as casas caiçaras transformaram-se em rugosidades. A antiga vila camponesa de Picinguaba apresenta hoje uma estrutura urbana, com uma série de serviços de abastecimento de água, coleta de lixo, entre outros, para atender a demanda de veraneio e turística.

De certa forma, pode-se afirmar que ocorreu uma migração interna na área de estudo, com o "esvaziamento" de ocupações de alguns sertões e a concentração maior de pessoas junto à orla. Isso se deve a duas ações que atuavam concomitantemente: às pressões do Parque, efetivadas pelos agentes ambientais; e a função turística que se dá mais junto à orla. Quer dizer, comunidades camponesas caiçaras que sofreram problemas com os agentes ambientais, acabaram migrando 
Raimundo, S.

para áreas da orla, mais atraentes do ponto de vista sócio-econômico, pois a função turística deste trecho trazia infra-estrutura e melhorava as condições sanitárias, além de oferecer oportunidades de trabalho. Um bom exemplo dessa situação pode ser constado no vale do Rio das Bicas, contíguo ao norte do vale do Rio da Fazenda. Nesse vale existiam poucas famílias que ocupavam parte da área, junto ao fundo de vale em 1977 e, em 2001 já não existiam mais enquanto formas de ocupação.

Assim, não ocorrem ocupações de novas áreas nos setores inseridos no Parque. Há um aumento radial das áreas já ocupadas (as vilas), que eram anteriores à criação desta Unidade de Conservação. O processo de difusão espacial na região entre o final da década de 1970 e início dos anos 2000, se dá, portanto, com a concentração de usos e ocupações junto à orla, aumentando as áreas das vilas préexistentes, ao mesmo tempo em que há um esvaziamento do sertão.

As condições de acesso é fator importante nessa análise. A comunidade do Cambury, no extremo norte da área de estudo, praticamente não mudou seu padrão espacial de ocupação. Mesmo possuindo características paisagísticas semelhantes a Picinguaba e a Almada, a Vila de Cambury praticamente manteve seu padrão de ocupação desde a década de 1970, a não ser pelo oferecimento de serviços na estrada, expressos pelos nós que ali se encontram. Isso não quer dizer que não ocorreu um processo de especulação imobiliária, pois como apontou Mansano (2004) ele foi intenso e trouxe em seu bojo a descaracterização sócio-cultural da comunidade.

Presentemente, a comunidade adaptou-se para absorver os turistas que pra lá se dirigem, principalmente na alta temporada - meses de verão, concentrados no Reveillon e no Carnaval. Mas é um fluxo menor em relação à Picinguaba e à Almada. Isso pode ser explicado pelas condições de acesso. A estrada que liga a vila à BR101 continua com seus $08 \mathrm{~km}$ sem serem pavimentados. Em épocas de chuva tornase intransitável. E é por isso que os moradores da vila reivindicam o asfaltamento da estrada, alegando que não usufruem mais intensamente das benesses que o turismo traz e, principalmente, como apontado por Silva (2004) pela necessidade de deslocamentos ao centro de Ubatuba em caso de emergência. A alegação dos responsáveis do Instituto Florestal pelo não asfaltamento desta estrada está associada ao temor de que os moradores caiçaras sucumbiriam à pressão imobiliária, que já existe na vila, pressão essa que se intensificaria com a melhoria de acessos; além de indicarem que não consideram o asfaltamento uma atribuição do órgão, que é responsável pela conservação da natureza e não pela melhoria das condições de acesso.

Apesar dessas divergências, considerando que melhoria das condições de acesso traz consigo um aumento da ocupação, o que fica, do ponto de vista da difusão espacial, é que o Parque também restringe o processo de difusão espacial do veraneio e do turismo, quando se coloca contra o asfaltamento desta estrada do Cambury. Nesse sentido, configura-se nesse bairro também como um elemento de 
impedância espacial, ou seja, uma resistência aos processos de ocupação.

Até aqui se pode dizer que as ações da iniciativa privada, através do turismo e da especulação imobiliária, favoreceram o processo de ocupação e de difusão espacial na região, enquanto as ações do poder público, notadamente ligadas ao Parque Estadual da Serra do Mar, impediram ou dificultaram esse processo de ocupação e de difusão.

Contudo, a Praia da Fazenda apresentou-se como um processo distinto a esse padrão. Os caminhos e cruzamentos nesse setor da área de estudo se dão pelo incentivo do próprio Parque. Foram construídos nessa praia, no final dos anos 1980, equipamentos para o atendimento ao visitante, como centro de visitantes, alojamento, biblioteca e lanchonete. O papel do Estado nessa praia, no que diz respeito à função espacial da área, acabou sendo semelhante ao desempenhado pela iniciativa privada nas praias vizinhas fora dos limites do Parque. Importante destacar que tais equipamentos são de uso coletivo e as casas de segunda residência na Picinguaba e Almada são de usos de particulares.

Nesse sentido, é oportuno indicar que o Parque assumiu ações similares às da pressão imobiliária no que diz respeito ao padrão de ocupação e de difusão espacial, mesmo considerando que os equipamentos construídos pelo Parque são de uso coletivo (público) e não particulares. Tal fato referenda a idéia de função atribuída pela sociedade majoritária à região (veraneio e turismo) e que é desenvolvida na Praia da Fazenda, tanto pela iniciativa privada, no Canto da Paciência (ponta oeste da praia) quanto pelo Parque Estadual da Serra do Mar, nos equipamentos voltados ao uso público no centro da praia. Com relação aos sertões, houve um decréscimo nos caminhos desde a década de 1970, indicando uma menor intensidade nos fluxos de pessoas e mercadorias nesse setor.

O Sertão da Fazenda possui uma concentração de nós. Tal fato pode ser explicado pelos mesmos processos indicados pelos equipamentos encontrados na Praia da Fazenda. Nesse sertão foi construída uma casa de farinha comunitária pela equipe do Parque Estadual da Serra do Mar, com a finalidade de resgatar a cultura caiçara local e ao mesmo tempo, incentivar a visitação nessa área. A casa de farinha apresenta esse nó de grande intensidade e, a partir dele, irradia nós de menores intensidades, que se expressam pelas trilhas das casas caiçaras até as roças e até essa casa de farinha comunitária.

É importante destacar também que nos sertões, as segundas-residências não são marcas tão intensas na paisagem, como freqüentemente se observa na orla. Isso porque, neles, o Parque Estadual exerce uma obstaculização aos processos de difusão espacial, ao mesmo tempo em que estes espaços não oferecem um apelo tão forte quanto a praia para a especulação imobiliária. Há poucas segundas-residências no sertão e elas ocorrem na maioria das vezes por pessoas que compraram posse como na orla, mas também por outras que se casaram com filhos de antigos moradores. Pode-se dizer assim, que a função de conservação do Parque, 
Raimundo, S.

consolidou-se no sertão antes que a pressão imobiliária se instalasse e se estruturasse como o fez na faixa de praia.

Fora do eixo da BR-101, há ainda trilhas e estradas que cortam a Unidade de Conservação pelos sertões gerando nós. Os mais significativos estão nos sertões do Poruba, de Ubatumirim e da Fazenda

No Sertão do Poruba, os nós de maior intensidade estão situados junto ao limite do Parque. À medida que a rede de caminhos adentra ao Parque nesse sertão, decrescem em intensidades de fluxos. Uma das explicações para este fato está associada à regularização fundiária. No Poruba, as terras de antigos proprietários (não moradores) só foram desapropriadas recentemente. Os nós das trilhas e caminhos que se encontram nesse sertão foram abertos pelos antigos proprietários e que ainda recentemente faziam a manutenção dessas estradas.

Importante verificar qual será o comportamento da ocupação, expressa pelos nós no bairro do Poruba, à medida que as ações de fiscalização serão realizadas exclusivamente pelos agentes do Parque. Até então, havia vigias contratados pela empresa que realizavam a guarda da propriedade.

No Sertão de Ubatumirim não existem nós dentro dos limites do Parque. As trilhas e estradas, embora adentrem os limites do Parque, não se configuram numa rede de nós. A trilha do Telégrafo, que existe desde o século XIX nesse sertão, é a única que atravessa o Parque e interliga a comunidade à Parati.

Em Ubatumirim, fora dos limites do Parque (abaixo da cota de 100m), a intensidade e densidade destes cruzamentos é relativamente baixa, sendo o nó mais significativo o encontrado na intersecção do final da estrada asfaltada com as estradas de terra, que é o ponto de confluência dos caminhões dos produtores e atravessadores que trabalham nas plantações de banana.

Ubatumirim é o sertão mais populoso e com maiores transformações na paisagem dos sertões estudados. Desta maneira, é possível indicar que a função agrícola comercial dos bananais deste bairro é a responsável por tais transformações. A vocação de veraneio e de turismo é insipiente, como em todos os sertões e essa intensidade de ocupação é reflexo desses usos voltados à função agrícola do sertão. Contudo, o Parque parece ainda frear as ações de implantação de novos bananais, à medida que não ocorrem nós além dos limites da Unidade de Conservação. Estes bananais guardam certa relação com o turismo e veraneio na área, pois parte da comercialização desta fruta se dá na região com as vendas diretas aos turistas e aos bares e restaurantes, assim como as técnicas e o manejo do plantio da banana pode apresentar potencial para visitas e o incremento do turismo.

Seja em relações mais diretas ao turismo, como a praia, a serra e as cachoeiras, seja em relações indiretas, como essas dos bananais de Ubatumirim, a área inserida do Núcleo Picinguaba apresenta $\mathrm{m}$ forte apelo ao turismo, como se tentará demonstrar a seguir. 


\section{- Parque Estadual da Serra do Mar (Núcleo Picinguaba) usos atuais e potenciais para o turismo}

Admitindo-se as informações dos tópicos precedentes, é possível pensar na estruturação de um programa de turismo e de Ecoturismo para o Núcleo Picinguaba, considerando todas as dificuldades e potencialidades até aqui apontadas.

No interior do Núcleo Picinguaba, os maiores processos de transformação e de difusão espacial se dão em dois locais: um na Vila de Picinguaba, com características ainda pontuais e outro ao longo da estrada de acesso à comunidade do Cambury, com um arranjo linear ao longo da estrada. Para fins de planejamento e/ou zoneamento, há uma necessidade de disciplinar as ações ao longo da Estrada do Cambury, como apontado, e também ações para a Vila de Picinguaba.

O plano de manejo do Parque Estadual da Serra do Mar (SÃO PAULO, 2006) indica algumas ações para essas duas localidades, reconhecendo-as como comunidades tradicionais e propondo atividades ligadas à manutenção de sua cultura e à busca por alternativas de renda associadas ao turismo (não ao veraneio). O plano de manejo classificou essas duas áreas, além do sertão da Fazenda e Ubatumirim como Zona Histórico-Cultural-Antropológica de Ubatuba.

A Zona Histórico Cultural Antropológica, abrange os bairros de Cambury, Vila de Picinguaba, Sertão da Fazenda e Ubatumirim. São localidades onde residem famílias caiçaras e/ou quilombolas há várias gerações... Apesar da forte pressão turística imobiliária para aquisição destas áreas por veranistas ou empreendedores, existe forte interesse destas comunidades em desenvolver atividades sustentáveis ligadas a agrofloresta, ao palmito e plantas ornamentais, bem como continuar com a agricultura de subsistência, com o artesanato e com a operação do turismo em bases mais sustentáveis. Cada uma destas comunidades tem suas particularidades: a Vila de Picinguaba já se constitui em um espaço urbano consolidado, apesar de inúmeros problemas decorrentes do seu desenvolvimento desordenado, com excessivo parcelamento e grande parte das áreas nas mãos de veranistas, artistas ou comerciantes de fora. Ubatumirim é uma comunidade essencialmente rural, com tradição na produção de banana e mandioca. O Sertão da Fazenda, onde fica a Casa de Farinha do Núcleo Picinguaba, é ocupado por pequenos agricultores cujos descendentes já buscam maior integração com o mercado de trabalho voltado para os serviços e 0 turismo. $O$ Cambury,...reconhecido em parte como território Quilombola, é ocupado por pescadores e agricultores em situação semelhante ao sertão da Fazenda, sendo a comunidade um pouco mais organizada, e com maior contato com veranistas, que freqüentam e também ocupam posses na região. (SÃO PAULO, 2006, pp. 430-431) 
O Sertão da Fazenda apresenta ocupação histórica, com a paisagem marcada pelo uso tradicional caiçara, expresso pelas plantações de mandioca no sistema de coivara. Ao longo dos últimos 40 anos, o sertão da Fazenda se manteve como uma expressão do modo de vida caiçara, mas sem crescimento em área. O turismo e o veraneio, provavelmente pela pressão das ações do Parque, não substituíram as roças caiçaras, expressando-se nesse sertão apenas através de trilhas para o Ecoturismo, como a trilha do Corisco e pela Casa de Farinha, o principal nó nos sertões situados dentro dos limites do Parque.

Nesse sentido, a estruturação de um programa de Ecoturismo e de Educação Ambiental, devem considerar roteiros aos atrativos naturais, mas também às características sócio-culturais. Os primeiros já são desenvolvidos por monitores treinados pelo Parque. Visitas aos poços naturais do Rio da Fazenda e atrativos do ambiente florestal, já se consolidaram no sertão da Fazenda. Contudo, as festas, as danças e as demais práticas da comunidade são pouco trabalhadas num roteiro de Ecoturismo, que poderia complementar a oferta de atrativos e tornar a visita mais enriquecedora. Presentemente ela se dá apenas na contemplação do fabrico da farinha de mandioca na Casa de Farinha.

Algumas atividades são de difícil mapeamento e monitoramento na região, tais como: a caça, a extração de recursos naturais de uma maneira clandestina, notadamente o palmito (Euterpes edulis), assim como a criação de animais exóticos.

A caça e a extração de palmito Euterpe edulis são os principais fatores de impacto sobre a estrutura e dinâmica de todo o ecossistema. Como há vários indícios dessas atividades em áreas de floresta conservada, a extração seletiva de palmito constitui-se num impacto importante, tanto para a sobrevivência da própria espécie quanto da fauna e da flora a ela associada. (SÃO PAULO, 2006, p. 94)

Essas atividades ilegais transformam-se em problemas muito complexos. 0 palmito principalmente, possui uma rede de conexões, sendo presentemente extraído por quadrilhas muitas bem equipadas com rádios-comunicadores e armas pesadas, ao contrário de alguns anos atrás quando homens humildes e descapitalizados eram aliciados por pequenos fabricantes regionais para extração clandestina. Nesse sentido, embora ainda haja um corte clandestino realizado pelas comunidades locais, o principal problema é a atuação destes grupos organizados que deixam um rastro de destruição de pés de palmitos cortados por onde passam.

Considerando essas informações, o Parque consegue frear os processos de ocupação cujas ações se dão diretamente pela substituição da vegetação original por usos humanos, como desmatamentos para instalação de loteamentos ou roças, anuais ou perenes. Contudo, o Parque não consegue frear os usos ligados ao corte seletivo, como o do palmito, que tem uma reduzida expressão espacial e são escamoteados pela presença da vegetação arbórea, se dando, sobretudo em áreas 
mais interiorizadas da floresta, de difícil acesso e praticados por quadrilhas organizadas de outras regiões. Com isso, as equipes de fiscalização do Parque e demais agentes ambientais não conseguem ter ações mais efetivas de controle a estes grupos.

O caminho mais adequado para iniciar o processo de resolução destes problemas de difícil percepção e controle, está ligado ao planejamento de uso da paisagem e ao envolvimento dos moradores locais nas práticas de conservação. Quer dizer, a ação de infratores ligados aos grupos organizados pode ser reduzida quando a comunidade local passa a ser mais co-responsável pelas ações de proteção da natureza. E ações ligadas ao Ecoturismo podem ter um papel fundamental para contribuir para resolução destes problemas.

Todas as localidades da área de estudo apresentam trilhas com potencial para o Ecoturismo ou já operando. No Poruba há a trilha de longo percurso no sertão, interligando a localidade ao Vale do Paraíba, Município de Cunha. Em Ubatumirim, além da trilha do Telégrafo, já muito utilizada, há também outras no vale do Rio Iriri, que dão acesso a poços e cachoeiras. Na Almada, há a trilha interligando-a à Praia Brava da Almada e à Praia da Fazenda. No Cambury também há uma trilha de curta duração até um conjunto de cachoeiras ao longo do Rio Cambury. $E$ as trilhas mais utilizadas para o Ecoturismo situam-se na bacia da Fazenda, no sertão há a trilha do Corisco que parte da casa de Farinha e segue até o Município de Parati e na planície a trilha do Picadão da Barra.

Todos esses locais são vítimas da ação daqueles infratores, palmiteiros e caçadores. Incentivando-se o uso pelo Ecoturismo e agregando nessas práticas a participação da comunidade local é possível pensar na redução da ação desses infratores. Como observado em outras localidades do Parque Estadual da Serra do Mar, "onde há ecoturistas, não há infratores" (João Paulo Vilani, responsável pelo Núcleo Santa Virgínia, com. pessoal). Partindo deste pressuposto, o plano de manejo do Parque Estadual da Serra do Mar estabeleceu como objetivos e ações prioritárias, "planejar e implementar o ordenamento do turismo e das trilhas, o uso sustentável da floresta integrado à capacitação da comunidade [e a]...Educação Ambiental" (SÃO PAULO, 2006, p.431).

As trilhas para o Ecoturismo parecem então, ser uma das saídas adequada, pois além das características de envolver a comunidade local e afugentar infratores, sua intervenção na paisagem é reduzida, configurando-se de maneira linear e estreita. Dadas essas características, com freqüência percebe-se o dossel fechado nos ambientes serranos, impedindo ações mais diretas das chuvas sobre o solo, contendo a erosão. Além disso, tais trilhas não alteram significativamente o microclima, pois o dossel fechado impede a ação direta dos raios solares no solo e sub-bosque, como observaram para outras localidades do domínio da Mata Atlântica, Passold et.al. (2004), Robim et.al. (2004) e Robim (1999).

Contudo, é preciso sempre frisar que os ambientes em que a maioria destas 
trilhas se insere são de uma dinâmica muito frágil - as encostas de alta declividade da Serra do Mar. Por isso, preocupações com relação ao traçado devem ser observadas, pois freqüentemente, na época das chuvas, percebem-se alguns locais tendo de ser re-orientados, devido à queda de árvores ou movimentos de massa. Assim, não basta apenas inserir a comunidade como beneficiária destas áreas, dando-lhes alternativas de renda ligadas ao Ecoturismo. É preciso planejar o traçado destas trilhas, assim como introduzir técnicas de mínimo impacto da visitação, entre outras como o Visitor Impact Management - VIM - (GRAEFE et.al., 1990), método que trabalha com o uso de indicadores físicos, biológicos e sociais que, uma vez estabelecidos devem ser monitorados para avaliar se as condições originais não estão sendo alteradas; ou o Limite Aceitável de Câmbio, ou de Alterações - LAC - que preconiza um acordo entre os envolvidos nas práticas do Ecoturismo para que todas as atividades operadas fiquem restritas a um limite aceitável de alterações, limite esse que deve ser definido por especialistas e pela comunidade que habita a localidade (TAKAHASHI, 1997).

Em um processo de planejamento mais abrangente de uso e ocupação é importante que os ambientes da área de estudo - da planície, dos fundos de vale e das encostas dos morros e Serra do Mar - possam ser utilizados em parte pelas comunidades locais e resguardando outras porções maiores à conservação da natureza. E esse uso parcial dos ambientes exercidos pelas comunidades, pode torná-las aliadas na conservação dos ambientes, evitando ações de grupos clandestinos.

O Núcleo Picinguaba apresenta importantes ambientes bem conservados da Floresta Atlântica. Contudo, eles se situam predominantemente nas encostas da Serra do Mar. As intervenções propostas para essa área, mesmo as trilhas cuidadosamente planejadas, devem ter uma baixíssima interferência, pois apresentam um delicado equilíbrio dinâmico, no qual ações humanas devem ser evitadas.

Na planície costeira, a situação predominante é a de florestas secundárias, embora ainda haja remanescentes de florestas de planície em estágio maduro (primário) como as encontradas na bacia do Poruba. Nesse sentido, é fundamental garantir um continuum de ambientes bem conservados, desde o alto da Serra do Mar até a planície costeira, como esta do Poruba.

E uma vez garantido esse continuum, é possível relacionar as demandas atuais por roças e extrativismo das comunidades camponesas caiçaras dessas localidades, acordando com elas usos permitidos em parte destes ambientes que possuam condições de dar suporte às práticas agrícolas caiçaras ou outras demandas da comunidade local.

É nesse contexto que as atividades de Ecoturismo devem ser desenvolvidas. Considerando esse continuum de ambientes bem conservados, com a possibilidade de comparação dos locais da planície e da serra, num trabalho de vivência e interpretação ambiental. E complementando com visitas às plantações e demais 
formas de ocupação tradicional caiçara, reforçando as vivência e trocas culturais.

Nas áreas de planície costeira, a ação do veraneio e do turismo poderia ser praticada, mas limitada, ou circunscrita, às áreas onde já ocorrem, ou seja, as vilas caiçaras, como Picinguaba e Almada. Presentemente representam apenas 0,06\% da superfície do Núcleo Picinguaba (RAIMUNDO, 2007). E é interessante para a manutenção dos ambientes bem conservados da região que se mantenham dentro destes limites areais.

Não há lógica nem interesse em impedir que a sociedade pratique o turismo e mais que isso, que não possa visitar um local, como a área de estudo, que apresenta características naturais e culturais tão relevantes. E tais características fazem da região um local focado nas tendências mais recentes de práticas do turismo, como "a vontade de conhecimento do sítio e das populações locais" (BOYER, 2003, p.15). Mais que isso, o turismo constitui-se presentemente na principal fonte de renda das comunidades da orla da área de estudo. Se fosse possível e desejável impedi-lo, estaria agora agravando as condições de renda da comunidade local, pois as práticas tradicionais camponesas estão imbricadas com as de turismo e veraneio.

O turismo não é o problema, mas sim o veraneio. Isso porque, fora dos limites do Parque, há uma ocupação mais acelerada na orla, como o loteamento na Praia de Ubatumirim, responsável pela maior transformação dos ambientes de planície na área de estudo. Como a instalação deste loteamento foi retomada recentemente ele aumentará a fragmentação dos ecossistemas da planície, já desconectados dos ambientes serranos pelo eixo da BR-101.

E nesse sentido, com relação ao turismo e ao veraneio, além de cuidar para que os espaços da orla não sejam transformados em ambientes degradados, é preciso pensar também em como a cultura caiçara e seu território não podem ser ainda mais descaracterizados pelas ações e interesses dessas atividades.

Algumas práticas já podem ser observadas, como a comunidade da Almada que se organizou para impedir a construção de um hotel padrão três estrelas nessa comunidade (fora dos limites do Parque). Ou ainda na Vila de Picinguaba, classificada como zona histórico-cultural-antropológica no plano de manejo do Parque, e que favorece, portanto, a permanência dos caiçaras no interior desta Unidade de Conservação. E para implementar essa zona, foi montada uma câmara técnica, composta por técnicos e lideranças da comunidade, que estão elaborando um microzoneamento para a Vila, com a confecção de um plano de uso tradicional. Essa câmara técnica realizou, desde 2006, dez reuniões para discussão de propostas de uso para a vila.

O desafio maior desta câmara técnica é apontar diretrizes para a área já urbanizada da Vila de Picinguaba. Diretrizes essas que possam conciliar os usos do veraneio e turístico com as práticas caiçaras, evitando o aumento da desterritorialização destes últimos, reduzindo, portanto, o avanço areal destas vilas sobre os ambientes contíguos, que embora ainda reduzido configuram-se como uma 
tendência espacial de ocupação.

Além da questão da ampliação dos espaços ocupados, que resulta numa desterritorialização caiçara, essa câmara técnica deve pensar nas relações dentro da área da vila, com a mudança nas relações entre turistas e veranistas com os caiçaras, reduzindo os sub-serviços praticados por estes últimos. Mas isso é um processo social ainda em construção, cujas propostas ainda são embrionárias e morosas para serem implementadas. Mas o fato de existir essa câmara técnica é um indício de organização da comunidade local e indica que há possibilidades de mudança na estrutura social da área, hoje governada pelas ações do veraneio, turismo e pelos agentes ambientais do Parque.

Contudo, é preciso ter cautela para que algumas decisões dessa câmara técnica, ou de outras localidades, mesmo sob o argumento que seja adequado aos moradores tradicionais caiçaras garantindo a reprodução de seu modo de vida, não interfiram de uma forma mais intensa na paisagem natural da planície, que apresenta atualmente uma forte tendência de degradação. A permissão de uso nesses ambientes sem uma avaliação ambiental mais criteriosa (como, por exemplo, considerando as manchas dos ambientes ainda conservados nessa planície), pode aumentar sua desconexão com os demais ambientes, agravando a situação de conservação na região.

Ainda na planície costeira, mas fora dos limites do Parque, a área mais dinâmica de transformação da paisagem é o Sertão de Ubatumirim. A lógica de ocupação para instalação de agricultura comercial da banana pode resultar na evolução destes ambientes da planície para a condição de degradação. Ainda predominam ambientes de transição (estágio médio ou avançado de regeneração florestal, segundo Decreto 750) na paisagem, mas já ocorrem áreas mais alteradas, como as do entroncamento da estrada asfaltada que dá acesso ao sertão com a BR101, e no final desta estrada asfaltada, num nó de maior intensidade, junto à escola e ao posto de saúde da comunidade. É fundamental então, garantir a utilização das plantações de banana, dentro de uma lógica comercial, mas impedindo-as de avançarem sobre os ambientes de transição na planície de Ubatumirim.

Para tal, diferentemente do sistema itinerante das roças tradicionais caiçaras, a cultura comercial da banana precisa ser freada nas demandas por novas áreas, mantendo-se circunscrita aos espaços que ocupam atualmente. Isso porque, as áreas com bananais estão no limite de fragmentação dos ambientes de transição ou mesmo bem conservados deste sertão.

Nesse sentido, a estratégia mais adequada é dinamizar as técnicas de cultivo nas áreas já abertas. Assim, trabalhos ligados à avaliação da capacidade suporte destes ambientes já ocupados por bananais devem ser implementados. Trabalhos esses que avaliem os ótimos de utilização, ciclagem de nutrientes, propriedades do solo, técnicas de conservação, entre outras condições e garantam a produtividade dos bananais, sem precisar expandi-los em áreas. Uma tendência importante no 
sertão de Ubatumirim são as práticas de agroflorestas de alguns bananais. Uma agrofloresta pode ser definida como "um sistema de comunidades vegetais anuais e juntamente com plantas perenes de valor econômico, para garantir uma cobertura permanente do solo, reduzindo as perdas de nutrientes pela chuva e erosão" (JUNK, 1995, p. 58). Ainda segundo esse autor, estes sistemas apresentam resultados muito promissores, porque correspondem também às exigências ecológicas e às aspirações dos pequenos produtores, contribuindo para a fixação de população em áreas rurais, por providenciar muitos empregos.

Alguns agricultores plantam apenas as variedades "ouro" e "prata" da banana em Ubatumirim. Como essas variedades, ao contrário da "nanica", não necessitam de áreas de sol pleno (CATI, 2000), é possível consorciá-las com espécies arbóreas nativas da floresta. Com isso, podem-se garantir espaços com áreas não abertas, constituídas por bananais consorciados com espécies arbóreas da Mata Atlântica.

Num sistema agroflorestal, as árvores são mantidas, na lógica do agricultor para serem aproveitadas no futuro para fabricação de moirões de cerca, remos, canoas entre outros utensílios. E na lógica da conservação da paisagem e mesmo dos ecossistemas, elas também são mantidas pois, é melhor a ocorrência de bananais entremeados com a floresta (agrofloresta), que bananais cultivados num sistema monocultural.

O processo de difusão espacial dos bananais são os mais intensos nos sertões da área de estudo. Vindos da planície já adentraram os limites do Parque (cota altimétrica de $100 \mathrm{~m}$.), notadamente nos vales dos Rios Iriri e Papagaio (RAIMUNDO, 2007). Nesse sentido, trabalhos para frear o avanço areal dos bananais, mas ao mesmo tempo garantirem sua produtividade, são a prioridade e desafio deste sertão.

E tais trabalhos estão ligados à introdução de técnicas de capacidade suporte dos ambientes, assim como o manejo de agroflorestas nesses ambientes. Nesse contexto, o Ecoturismo pode ser implantado como alternativa complementar de renda para os produtores de banana de Ubatumirim. Isso pois, as técnicas de plantio de banana de Ubatumirim, sem utilização de agrotóxicos ou fertilizantes e consorciadas às florestas em alguns setores, apresentam grande potencial de visitação. Assim, podem se transformar num complemento de renda às familiares agricultoras deste bairro, à medida que o visitante pode usufruir das belezas naturais, como trilhas na floresta e cachoeiras deste bairro e visitar e aprender sobre uma técnica tradicional de produção comercial nos bananais, que é muito singular e adaptada às condições da região, transformando-se assim, num diferencial de visitação.

Considerando todas essas informações, pode ocorrer um choque com a legislação ambiental atual, sobretudo a do Parque Estadual, que proíbe quaisquer usos diretos de recursos naturais no interior da Unidade de Conservação. Assim, os usos ligados à pratica camponesa caiçara, ou mesmo do veraneio não poderiam ser desenvolvidos no interior do Parque.

Uma solução para esse problema pode ser a re-categorização de algumas 
Raimundo, S.

áreas do interior do Parque. O SNUC prevê este tipo de situação e apresenta como lógica a instituição de um mosaico de Unidades de Conservação. Mosaico este constituído por Unidades de Conservação de proteção integral, nas quais o uso dos recursos naturais só podem ser realizados de maneira "indireta", ou seja, não envolvendo consumo, coleta, dano ou destruição dos recursos. E estes usos devem ser consorciados com Unidades de Conservação de uso sustentável, nas quais os recursos naturais podem ter "uso direto".

Experiências similares já foram desenvolvidas no Estado de São Paulo, como na Estação Ecológica de Juréia-Itatins, nos municípios de Iguape e Peruíbe. Na antiga área dessa estação, com cerca de 80.000 hectares, foi criado um mosaico de Unidades de Conservação, mantendo áreas como de proteção integral (três Estações Ecológicas, sendo duas novas e dois novos Parques Estaduais) e criando outras de uso sustentável (Reservas de Desenvolvimento Sustentável). Esse mosaico foi aprovado pela Lei 12.406, de 2006, na Assembléia Legislativa de São Paulo.

Contudo, os trabalhos para o estabelecimento desse mosaico de Unidades de Conservação foram marcados por discussões políticas, com pressão de moradores e veranistas do interior da unidade e os técnicos do Instituto Florestal tentando relacionar tais demandas aos objetivos de conservação da Estação Ecológica. Nesse caso, não se considerou um mapeamento ou análise mais pormenorizada, baseada num mapa de unidades de paisagem, ou mesmo de características da vegetação na área da antiga estação ecológica.

Esse processo gerou algumas críticas, principalmente de profissionais e pesquisadores das ciências naturais, que indicam que alguns dos ambientes da Estação podem ser reduzidos ou eliminados da paisagem com a nova recategorização (CAMPOS et.al., 2007).

Ao contrário da Estação Ecológica de Juréia-Itatins, há uma oportunidade de conciliar os usos diversos que ocorrem no litoral norte de Ubatuba. Há vários trabalhos sobre a ação da sociedade sobre os ambientes naturais que compõem o Núcleo Picinguaba. Tais trabalhos podem contribuir para a indicação de áreas para instalação de Unidades de Conservação de uso sustentável, que junto com o Parque Estadual da Serra do Mar e o Parque Nacional da Bocaina, possam se constituir num mosaico de Unidades de Conservação.

Nesse sentido, a criação de um mosaico de Unidades de Conservação não pode deixar de considerar o processo de ocupação na região e sua difusão espacial, estabelecendo regras de uso e ocupação das áreas. Hoje, na orla, a difusão espacial está ainda muito restrita às antigas vilas caiçaras e se dá nessa porção de uma forma descontínua (pontual) na paisagem, excetuando-se o setor ao longo do eixo da BR101. A preocupação é que Unidades de Conservação de uso sustentável possam agilizar esse processo de difusão.

Da mesma forma, os bananais em Ubatumirim precisam ter um espaço bem delimitado para suas práticas, assim como normas que evitem sua difusão espacial, 
pois, como se trata de uma lógica agrícola comercial, se forem eliminadas as barreiras legais/espaciais que o Parque exerce, quando ocorrer a transformação para uma unidade de uso sustentável, tais bananais podem apresentar padrão de difusão espacial similar aos discutidos por Mello (2006) Moran e MacCraben (2004) para Amazônia, nos quais em 30 anos foram desmatadas extensas áreas de forestas.

Para a área da Vila de Picinguaba, precisa-se tomar atenção para que recategorizações, como as já propostas pelas câmaras técnicas estabelecidas pelo plano de manejo, mudem o processo de ocupação que ainda é pontual. A mudança para outro padrão, de expressão espacial menos interessante para a conservação dos ambientes, como o linear ao longo da estrada de acesso ou ainda generalizado, em várias direções, pode piorar as condições dos ecossistemas contíguos à vila.

No sertão da Fazenda, é importante pensar que a transformação em uma nova Unidade de Conservação de uso sustentável, possa refuncionalizar o bairro. Atualmente o turismo (e não o veraneio) é uma atividade complementar das práticas tradicionais caiçaras. Uma mudança de categoria poderia acirrar a ocupação por áreas destinadas ao veraneio, atividades que hoje não se notam no sertão da Fazenda e que são as responsáveis pelas maiores transformações culturais e espaciais na área de estudo. Melhor pensar na relação das práticas camponesas caiçaras com o Ecoturismo nesse bairro, discutindo com a comunidade as atividades adequadas para visitas de ecoturistas, assim como para uma complementação de renda a comunidade oriunda dessa atividade.

Garantir-se-ia as práticas de Ecoturismo, que é um dos objetivos do Parque, ao mesmo tempo em que poderiam incrementar a renda desta comunidade. Contudo, aquelas recomendações sobre o traçado e planejamento das trilhas precisam ser implementadas, pois elas irradiam a partir da Casa de Farinha, para os ambientes serranos, os mais frágeis da área de estudo.

E as práticas camponesas caiçaras que ocorrem no bairro não apresentam um padrão de ocupação e de difusão que possam se expressar por todos os ambientes da comunidade. Enquanto se manterem com essa lógica - numa função de agricultura camponesa e de Ecoturismo -, que rebate espacialmente de maneira pontual e descontínua na paisagem, os ambientes conservados contíguos não serão alterados. Desta forma, as práticas tradicionais caiçaras podem ser desenvolvidas numa Unidade de Conservação de proteção integral, sem necessariamente discutir uma mudança de categoria. Mais que isso, essas práticas tradicionais poderiam estar associadas ao Ecoturismo, atendendo a demandas e necessidades dos principais atores da região. A transformação deste bairro em "Zona Histórico-CulturalAntropológica de Ubatuba" do plano de manejo do Parque Estadual acena para a resolução destes conflitos, mas ainda será necessário um detalhamento e uma normatização das atividades destas zonas, atividades essas que devem ser discutidas entre a comunidade e os técnicos do Instituto Florestal. 
Raimundo, S.

\section{Considerações Finais}

Admitindo-se as informações aqui relatadas, apresentam-se como considerações finais a necessidade premente da elaboração de um microzoneamento ao plano de manejo do Parque Estadual da Serra do Mar, encerrado em 2006. Este micro-zoneamento, que deve ter como objetivo detalhar o ordenamento do processo de uso e ocupação do solo no Núcleo Picinguaba, deve considerar o turismo (e também o Ecoturismo), mas principalmente o veraneio, como as principais práticas transformadoras da paisagem na área, tentando minimizar os impactos negativos oriundos dessas atividades.

Assim, devem-se estabelecer tais ordenamentos das áreas ocupadas, como ao longo da estrada de acesso ao Cambury. Com isso, espera-se que haja utilização para atividades sócio-econômicas em parte dos ambientes de planície e serranos, garantindo melhorias como a perenização da estrada de acesso, mas também resguardar parte dos ambientes naturais para a conservação integral, evitando sua fragmentação ou sua total supressão. Importante destacar que esse ordenamento deve ser estabelecido em conjunto com as comunidades afetadas / beneficiadas para que tenha êxito. Seja numa área quilombola ou no Parque, é fundamental considerar o mapeamento e a dinâmica da paisagem natural, como apontado em Raimundo (2007) para implementação das atividades sócio-econômicas, garantindo os espaços de ambientes bem conservados.

Nessa mesma linha, deve-se pensar na implantação de técnicas de melhoramento da produtividade dos bananais de Ubatumirim, evitando que eles tenham um aumento areal na bacia. Trata-se da área com as maiores manchas de ambientes degradados e cuja lógica de ocupação apresenta a maior difusão espacial nos sertões da área de estudo. Estudos de capacidade suporte dos ambientes, de Etnoconservação e a introdução de sistemas agroflorestais devem ser implantados com urgência para quebrar esse processo de difusão espacial. Já há experiências na comunidade com agroflorestas, mas elas precisam ser estendidas para todas as plantações na bacia. Contribuindo como um complemento de trabalho e renda, atividades voltadas ao Ecoturismo e turismo cultural podem ser estabelecidas, com visitas monitoradas à paisagem natural (cachoeiras, florestas) e às técnicas tradicionais de manejo desta comunidade. Nessa, deve-se focalizar como a comunidade local apreendeu a interagir com o meio, desenvolvendo suas técnicas de produção.

$\mathrm{Na}$ orla dentro dos limites do Parque, é fundamental manter o processo de ocupação para o veraneio e turismo circunscrito às antigas vilas caiçaras, evitando que apresentem um padrão mais generalizado. Mas é importante quebrar o processo de desterritorialização caiçara nessas áreas, evitando sua incorporação às práticas sócio-econômicas apenas como meros serviçais. O planejamento participativo nas câmaras técnicas do conselho consultivo do Parque tem trabalhado para evitar esses problemas. E trabalhos ligados à Geografia Cultural e a Etnoconservação podem 
contribuir para melhorar os diagnósticos das necessidades, aspirações e representações das comunidades caiçaras.

Ainda na orla, mas fora dos limites do Parque, deve-se evitar a instalação de loteamentos como o da Praia de Ubatumirim. Ou fazê-lo considerando a diversidade dos ambientes naturais e o mapeamento da paisagem natural, a fim de evitar o aumento da fragmentação de ambientes na planície costeira, os mais alterados na área de estudo. Para a Vila da Almada, é importante pensar em ações semelhantes às propostas para a Vila de Picinguaba: a montagem de um conselho de moradores tradicionais que discuta sua relação com os veranistas e turistas. Já há condições para o estabelecimento de um conselho na comunidade, pois ela organizadamente conseguiu impedir a construção de um hotel na praia.

É importante também, considerar informações sobre os processos de difusão espacial das ações da sociedade sobre as características e arranjo espacial dos ecossistemas para uma possível proposta de mudança de categoria do Parque para outras categorias de uso sustentável ou áreas quilombolas nos setores com ocupação. Com isso, criar-se-ia um mosaico de Unidades de Conservação que consideraria e protegeria as características naturais da região, assim como contribuiria para minimizar os impactos sócio-culturais dos atores hegemonizados (caiçaras e quilombolas).

\section{Referências}

ABLER, R.; ADAMS, J.S..; GOULD, P. Spatial organization: the geographer's view of the world. Prentice-Hall: Englewood Cliffs, New Jersey, 585p.

ARRUDA, R.V. 1997. Populações Tradicionais e a Proteção dos Recursos Naturais em Unidades de Conservação - Anais do I Congresso Brasileiro de Unidades de Conservação - Curitiba PR 15 a 23/11/1997 - Org.: SMA PR - Fundação O Boticário Instituto Ambiental do Paraná, 1971. pp. 351-367.

BOYER, M. 2003. História do turismo de massa. Tradução Viviane Ribeiro. Bauru: Edusc, 170p.

BRITO, M.C.W. Unidades de Conservação: intenções e resultados, São Paulo:Anablume: Fapesp, 2000. 230 p.

CAMPOS, F. P.; RAIMUNDO, S.; OLIVEIRA, R. C. R. Criação do Mosaico JuréiaItatins: Esbulho Político, Proposta Técnica e Solução Desvirtuada, São Paulo, Brasil. In: II Congresso Latino Americano de Parques Nacionais e outras Áreas Protegidas, 2007, Bariloche - Argentina. Anais do II Congresso Latino Americano de Parques Nacionais e outras Áreas Protegidas, v. 1.2007. 
Raimundo, S.

CATI (Serviços e Produtos para a Agricultura). Projeto Agricultura Caiçara em Ubatuba. (Fotocópia), 2000. 05p.

CEBALLOS-LASCURAIN, H. O Ecoturismo como um fenômeno mundial. In: LINDBERG, K. \& HAWKINS, D. (editores). Ecoturismo: um guia de planejamento e gestão, tradução de Leila Cristina de M. Darin, São Paulo: Ed. Senac São Paulo, 1995. pp. 23-30.

DIEGUES, A.C.S. Saberes tradicionais e etnoconservação. In: DIEGUES, A.C.S. \& VIANA, V. (orgs.). Comunidades tradicionais e manejo de recursos naturais da mata atlântica. São Paulo: Nupaub-USP, 2000a. pp. 09-22.

DIEGUES, A.C.S. Etnoconservação da natureza: enfoques alternativos. In: DIEGUES, A.C.S. (org.). Etnoconservação: novos rumos para a proteção da natureza nos trópicos. São Paulo: Ed. Hucitec, 2000b. 290p.

DIEGUES, A.C.S. As áreas naturais protegidas, o turismo e as populações tradicionais. In: SERRANO, C. \& BRUHNS, H. (orgs.). Viagens à natureza: turismo, cultura e ambiente. Campinas: Papirus, 1998, pp. 85-102.

DIEGUES, A.C.S. Populações tradicionais em Unidades de Conservação: o mito moderno da natureza intocada. São Paulo: Nupaub-USP, série documentos de pesquisa, $n^{0} 1,1993,66 p$.

DIEGUES, A.C.S.; NOGARA, P. 0 nosso lugar virou parque: estudo sócioambiental do Saco do Mamanguá - Parati - Rio de Janeiro. São Paulo: Nupaub/ Cemar-Usp, 1994. 187p.

GRAEFE, A. R.; KUSS, F.R.,; VASKE, J.J. Visitor Impact Management: The Planning Framework. Washington, DC: National Parks and Conservation Association, 1990. 105p, (Vol. 2).

HAUFF, S.N. Relações entre Comunidades Rurais Locais e Administrações de Parques no Brasil: Subsídios ao Estabelecimento das Zonas de Amortecimento. (Tese de doutorado). Universidade Federal do Paraná, Setor de Ciências Agrárias Centro de Ciências Florestais e da Madeira. Programa de Pós-Graduação em Engenharia Florestal, 2004. 184p + anexos.

JUNK, W. Capacidade suporte de ecossistemas: Amazônia como estudo de caso. In: TAUK-TORNISIELO et.al. (orgs.). Análise ambiental: estratégias e ações. São Paulo: T. A. Queiroz/Fundação S. F. Malu, Rio Claro - Centros de Estudos Ambientais - Unesp, 1995. pp. 51-62.

MANSANO, C. Do "tempo dos antigos" ao "tempo de hoje": o caiçara de Camburi, entre a terra e o mar. In: DIEGUES A.C. (org.) Enciclopédia Caiçara, Vol. 1. São Paulo: Hucitec: Nupalb: CEC/USP, 2004. pp. 193-224. 
MCCORMICK, J. Rumo ao paraíso: a história do movimento ambientalista; tradução: Rocha, M.A. E. Aguiar, R. Rio de Janeiro: Relume-Dumará, 1992. 234p.

MELLO, N.A. Políticas territoriais na Amazônia. São Paulo: Ananablume, 2006. $412 p$.

MILANO, M.S. Unidades de Conservação. Conceitos básicos e princípios gerais de planejamento, manejo e administração. In: Curso de Manejo de Áreas Naturais Protegidas. Curitiba: UNILIVRE. 1997. pp.1-60.

MILLER, K.R. Evolução do conceito de áreas de proteção - oportunidades para o século XXI. In: Congresso Brasileiro de Unidades de Conservação (1)1997: Curitiba) Anais. Curitiba: IAP:Unilivre: Rede Nacional Pro Unidade de Conservação,2v.1997. pp.3-22

MORAN, E.; MCCRACKEN, S. The developmental cycle of domestic groups and Amazonian Deforestation. Ambiente \& Sociedade, vol. VII, n², 2004. pp.11-44

MORSELLO, C. Áreas protegidas públicas e privadas: seleção e manejo. São Paulo: Annablume: Fapesp, 2001.344p.

MOURÃO, F.A. 2003. Os pescadores do litoral sul de São Paulo. São Paulo: Nupalb/CEC Hucitec, 264p.

MOURÃO, F.A. 1971. Os pescadores do litoral sul de São Paulo. (Tese de doutorado), FFLCH, da Universidade de São Paulo, 233p.

OLIVEIRA, L.R.N.; BARROS, M.R.; MARETTI, C. C. \& RAIMUNDO, S. 1998. Planos de manejo das Unidades de Conservação: Parque Estadual da Serra do Mar Núcleo Picinguaba - plano de gestão ambiental - fase 1. São Paulo: SMA, 183p.

OLMOS, F. et.al. 2001. Correção política e biodiversidade: a crescente ameaça das "populações tradicionais" à Mata Atlântica. In: ALBUQUERQUE...J.L.B.ed.)(et.al.). Ornitologia e conservação: da ciência às estratégias, Tubarão: Unisul, pp. 279-312.

PASSOLD, A.J.; MAGRO, T.C.; COUTO, H. Comparing Indicator Effectiveness for Monitoring Visitor Impact at Intervales State Park, Brazil: Park Ranger-Measured Versus Specialist-Measured Experience. In: Second International Conference on Monitoring and Management of Visitor Flows in Recreational and Protected Areas, 2004, Rovaniemi. Policies, Methods and Tools for Visitor Management. Proceedings of the Second International Conference on Monitoring and Management of... Saari jarvi : Finnish Forest Research Institute, 2004. pp. 51-56 
Raimundo, S.

PESCARINI, A. Relatório da Comissão Especial de Inquérito para promover o levantamento e estudar os problemas das áreas verdes pertencentes ao Estado e a de particulares - 1978. Caderno Ciências da Terra, $\mathbf{n}^{\circ}$ 64. Instituto de Geografia Universidade de São Paulo, São Paulo. 1981. 24p.

RAIMUNDO, S. As Ondas do Litoral Norte (SP): Difusão espacial das práticas caiçaras e do veraneio no Núcleo Picinguaba do Parque Estadual da Serra do Mar

1966-2001). (Tese de doutorado), Instituto de Geociências da Universidade Estadual de Campinas (Unicamp), 2007. 350p. + anexos.

ROBIM, M.J. Análise das características do uso recreativo do Parque Estadual da llha Anchieta: uma contribuição ao manejo. (Tese de doutorado). Centro de Ciências Biológicas e da Saúde. Univ.de São Carlos, São Carlos (SP), 1999. 161p.

ROBIM, M.J.; FONTES, M.A.; CAVALHEIRO, F. Determinação da capacidade carga da trilha da Praia do Sul no Parque Estadual da Ilha Anchieta: uma aplicação do método de Cinfuentes. In: SANTOS, J.E. dos, CAVALHEIRO, F., PIRES, J.S.R., OLIVEIRA, C.H. \& PIRES, A.M.Z.C.R. (Org.). Faces da polissemia da paisagem: ecologia, planejamento e percepção. 1 ed. São Carlos: Rima Editora, v. 1, 2004. pp. 97-110.

RODMAN, J. What is living and what is dead in the political phylosophy of T. H. Green, The West Political Quarquely, 26, 1973. pp. 566-586.

SÃO PAULO - INSTITUTO FLORESTAL / SECRETARIA DE ESTADO DO MEIO AMBIENTE. Plano de Manejo do Parque Estadual da Serra do Mar. Relatório não publicado. 2006.

SILVA, S.R. Camburi, território de brancos, negros e índios no limite do consenso caiçara: transformações de uma população tradicional camponesa. (Dissertação de mestrado). São Paulo, Depto de Geografia - FFLCH - USP. 2004. 212 p.

SNUC. Sistema Nacional de Unidades de Conservação, Lei Federal $n^{\circ}$ 9.985, de 18 de Julho de 2000.

TAKAHASHI, L.Y. Limite aceitável de câmbio (LAC): manejando e monitorando visitantes. In: Congresso Brasileiro de Unidades de Conservação, 1997, Curitiba. Congresso Brasileiro de Unidades de Conservação. Curitiba: Instituto Ambiental do Parana (IAP) / UNILIVRE/ Rede Nacional Pró Unidades de Conservação, v. 1. 1997. pp. 445-464.

TERBORGH, J.; Van SCHAIK, C. Por que o mundo necessita de parques? In: SPERGEL, B.; TERBORGH, J.; (et.al.) (orgs.). Tornando os parques eficientes: Curitiba: Ed. UFPR / Fundação o Boticário, 2002. pp. 25-51. 
THOMAS, K. Homem e o mundo natural: mudanças de atitude em relação às plantas e aos animais (1500-1800). São Paulo: Companhia das Letras, 1988. 454 p.

URBAN, T. Saudades do Matão: relembrando a história da conservação da natureza no Brasil, Curitiba: Editora da UFPR; Fundação O Boticário de Proteção à Natureza; Fundação MacArthur, 1998. 374p.

VIANNA, L.P. Considerações críticas sobre a construção da idéia de "População tradicional" no contexto das Unidades de Conservação. (Dissertação de mestrado). Depto de Antropologia, FFLCH-USP, 1996. 232p.

Sidnei Raimundo, geógrafo, Prof. Dr. do Curso de Lazer e Turismo da Escola de Artes, Ciências e Humanidades da Universidade de São Paulo (EACH-USP);

Email: sraimundo@usp.br;

Link para o currículo Lattes: http://lattes.cnpq.br/0352060547192132.

Data da Submissão: 05 de maio de 2008

Data de aceite: 29 de maio de 2008 